\title{
CONTRACTUAL DELEGATION OF SOVEREIGNTY IN SUPRANATIONAL ENTITIES
}

\author{
Zhanna Zavalna ${ }^{\mathbf{1}}$, Mykola Starynskyi
}

Received: 2021-06-03

Accepted: 2021-07-14

DOI: http://doi.org/10.46489/gpj.2021-1-2-5

\begin{abstract}
The article analyses the agreement basis for state sovereignty as established and implemented in the European Union. The research aims to study the agreement-based regulation used by the EU Member States to create a stable position of Ukraine on its way to becoming a member of the European Union. The research allowed finding out that the member states do not transfer their powers in their economic and social fields but only delegate them. The analysis of the treaties concerning the establishment and functioning of the European Union proves the existence of specific organisational and legal intervention measures that the countries agree to when joining the treaty union. The agreement-based rearrangement of powers between the EU and its member states lets the latter obtain their special legal personalities regarding the conclusion of agreements among themselves and at the same time preserve complete economic sovereignty in their relations with the countries that are not member states of the EU. When joining the European Union, its member states voluntarily and on a negotiable basis agree to certain restrictions and prohibitions binding in their economy. Furthermore, the EC Treaty provides for the improved protection of interests for the economic community as compared with the protection of national interests of the member states though it is not excluded that the latter can be taken into consideration when adopting the national laws of a member state to the EU legislation.
\end{abstract}

Keywords: treaty, treaty union, European Union, powers, cooperation, community, sovereignty.

\footnotetext{
1 Zhanna Zavalna, Doctor of Law, Professor, Professor of the Department of Civil Law, V.N. Karazin Kharkov National University, Kharkyv, Svobody sq., 4, 61 022, Ukraine, e-mail: zavaln@karazin.ua, ORCID: https://orcid.org/0000-0001-6511-2482

2 Mykola Starynskyi, Doctor of Law, Professor, Professor of the Department of Administrative, Economic Law and Financial and Economic Security, Academic and Research Institute of Law, Sumy State University, Sumy, Rimskogo-Khorsakova str., 2, 40000, Ukraine, e-mail: starinskiy_nik@ukr.net, ORCID: https://orcid.org/00000003-2661-5639
} 


\section{ВСТУП}

Європейський вибір прийнято вважати невід'ємною складовою національної ідеї і одночасно стратегічним напрямом державноправового розвитку України, внаслідок чого курс на європейську інтеграцію $\epsilon$ найважливішим зовнішньополітичним пріоритетом України. Кожна держава, яка взяла напрямок на інтеграцію у європейський економічний простір, постала перед завданням обрання одного $з$ двох напрямків розвитку конкуренції чи співробітництва. На сьогоднішній день, для врівноважування цих двох антагоністичних сил держави укладають різного роду договори, в тому числі про створення наддержавних співтовариств. Одним із таких державних об'єднань $\epsilon$ Європейське співтовариство. Європейський Союз виставив доволі жорсткі умови для набуття членства. Це можна пояснити тим, що Європейський Союз хоче бачити серед своїх членів тільки ті держави, які належать до європейського цивілізаційного пласту, і сприймають та впроваджують у своє політичне i економічне життя цінності об'єднання, а не будь-яку державу, яка географічно належить до Європи. Умови вступу до Європейського Союзу були ускладнені на етапі прийняття в союз країн Центральної і Східної Європи (Falalieieva L. H., 2017.).

Існування та розширення меж Європейської спільноти відбулось на основі цілої низки договірних актів (Маастрихтський договір, Ніццький договір - далі Договір про ЄС, ДЕС), які втілюють доволі цікаві як для теорії, соціології, економіки права умови входження та перебування держав в такому співтоваристві. Аналіз та дослідження основоположних статутних документів $є$ необхідним для вивчення досвіду функціонування держав-учасниць в договірних наднаціональних союзах 3 метою формування сталої позиції на шляху входження України до Європейського Союзу.

Здатність Європейського Союзу сприяти ефективному вирішенню завдань та реалізації економічних функцій держав $\epsilon$ одним із головних факторів, що обумовлюють доцільність його існування як для держав-учасниць, так i для країн-сусідів та державкандидатів, а також виправдовує практику делегування державамиучасницями наднаціональному утворенню своїх суверенних прав та повноважень. Для кращого розуміння проблем державно-правового розвитку в умовах інтегрування держав в європейський простір, необхідно постійно проводити всебічний аналіз теорії i практики реалізації своїх функцій державами в умовах їх членства в договірному міждержавному об'єднанні. Дослідження проблем європейської інтеграції здійснювали науковці, які в своїх дослідженнях вивчали питання загальних засад створення та функціонування економічного та валютного союзу (Butorina, O., 2001, Butorina, 0., 2005), проблеми реалізації державами свого фінансового та економічного суверенітету в глобалізаційних умовах (Petryshyn, O. V, 2010), проблеми реалізації внутрішніх функцій держави в умовах членства в Європейському союзі (Salo, V. I., 2001.); правові питання інтеграції України в ЄC (Siur, N. V., 2006); правових основ інтеграції в $€ C$ (Yakoviuk, I.V., 2004; Yakoviuk, I.V. 2010; Yakoviuk, I.V., 2013). Іноземні автори, приділяли увагу суверенітет в договірних об'єднаннях держав, обговорювали проблеми подільності (Bruno de Witte, 1995) та делегування суверенітету (David A. Lake, 2006), а також позицію Конституційного Суду ФРН в рішенні про державний суверенітет (Roland Bieber, 2009). 
На фоні розмаїття наукових досліджень глобалізаційних процесів залишаються недостатньо висвітленими питання договірного регулювання встановлення та реалізації суверенітету державами-учасницями, які перебувають в міждержавних союзах, зокрема в Європейському Союзі.

\section{РЕЗУЛЬТАТИ}

На сьогоднішній день, в міжнародному праві діє базова теорія європейської інтеграції, яка утверджує позицію співробітництва держав на основі об'єднання суверенітетів. Це означає, що суверенітети держав замінюють i не конкурують один 3 одним, але примножують сили i можливості кожного 3 учасників міждержавного об’єднання. Розгорнуте закріплення змісту принципу наділення компетенцією, що міститься в Лісабонській редакції Договору про ЄС містить дає підстави говорити про те, що держави-учасниці остаточно не передають інститутам $€ C$ свої повноваження у певних сферах. Крім того, введення в нормативне регулювання положення про можливість реалізації свого права на вихід зі складу Європейського Союзу ще раз підтверджує думку про те, що держави-учасниці

залишають суверенними протягом всього часу перебування у міждержавному об'єднанні. Тому мова скоріше йдеться про встановлення певної компетенції для $€ \mathrm{C}$, а також про реалізацію тих повноважень, які держави-члени визнали за доцільне делегувати на наднаціональний рівень за для ефективного здійснення своїх економічних функцій.

Щоб залишатись повноправним суб'єктом міжнародного права, держава має бути суверенною i залишатись такою при входженні в будь-які міждержавні об'єднання. Для цього необхідно, щоб функції і компетенції залишались за державою в повному обсязі, оскільки суверенні права $\epsilon$ невід'ємними правами держави, тому, що базуються на національних нормативних актах. Така позиція відстоюється державами-членами Європейського Союзу, які в договірному порядку передали інститутам Європейського Союзу не самі суверенні права, а тільки можливість їх реалізації чи точніше - підконтрольне їх здійснення.

Рішенням Конституційного Суду ФРН, яке стосувалося питання збереження/передання державного суверенітету у міждержавних союзах, було встановлено, що положення Конституції не уповноважує уряд на передачу суверенних прав держави, а тільки такий спосіб побудови правопорядку, за якого допускається застосування права з іншого джерела в рамках внутрішньодержавної компетенції (Oona A. Hathaway, 2008). Аналіз даного положення показує, що Конституційний Суд відстоює позицію делегування здійснення суверенних прав, що показує факт залишення прав за собою і не йдеться про остаточне відчуження суверенних прав чи окремих повноважень. В даному випадку також йдеться про можливість спільної, разом 3 інститутами $€ C$, реалізації частини внутрішніх повноважень держави до того часу, доки держава виявляє волю бути членом договірного об'єднання (Klemin, A. V. 1996).

Аналіз установчих документів ЄС, а також інших політичних та правових актів, які оформлюють започаткування та здійснення інтеграційного процесу, показує, що держави добровільно делегують свої повноваження, по суті здійснюючи самообмеження щодо реалізації окремих суверенних прав в рамках свого внутрішнього i зовнішнього суверенітету. В даному випадку йдеться не про остаточне вилучення певних повноважень із предмета компетенції держави, а про зміну суб’єкта, що її здійснює. Держави, 
які при плануванні свого подальшого економічного розвитку віддали перевагу концепції співробітництва, добровільно погоджуються на обмеження самостійної реалізації окремих суверенних прав, оскільки очікують від інших держав-учасниць договірного союзу, таких самих кроків. При цьому не інституції Європейського Союзу встановлюють обсяг прав, що передаються, а самі держави-члени. Останні, визначаючи обсяг компетенції, який вони передають інституціям $€ \mathrm{C}$, а також встановлюють рамки для здійснення заходів і рішень Європейською радою і Радою ЄС як інститутів міжурядової співпраці. Дані інституції здійснюють передані повноваження на наднаціональному рівні відповідно до мандату, яким наділила їх кожна із держав учасниць (Yakoviuk, I.V. 2013).

Пропонуємо звернутись до тексту Договору про ЄC i проілюструвати конкретні способи та методи делегування конкретних повноважень держав-учасниць. В Договорі про ЄС передбачається делегування органам $€ \mathrm{C}$ повноважень різних сфер життєдіяльності держави. Пропонуємо розпочати аналіз із повноважень в сфері правотворення та правозастосування. В Договорі про ЄС чітко прослідковується, що держави-учасниці добровільно погоджуються на скасування національних нормативних актів повністю та в частині, якщо вони встановлюють адміністративні процедури та звичаї, а також права, що випливають 3 національного законодавства чи угод між державамичленами, укладених раніше, та що перешкоджають лібералізації вільного пересування працівників, свободі підприємницької діяльності, руху капіталу, розміщення інвестицій тощо. Також, органам $€ C$ встановлюються повноваження на тлумачення окремих статей при їх застосуванні. Так, Комісія $€ C$ може надавати державам-членам рекомендації щодо застосування окремих статей (ч. 3 ст. 77 Договору про $\epsilon C)$.

В договорі про ЄС встановлюються правила ведення переговорів та укладення угод в середині Спільноти, тобто в договірному порядку відбувається переформотування повноважень на встановлення договірного регулювання відносно держав-учасниць. Більш того, спеціально наголошується на обов'язковій силі таких угод для всіх інституцій Спільноти та державучасниць (ч. 3 ст. 111 Договору про ЄС; ч. 3 ст. 133 Договору про ЄC). В даному випадку можна говорити встановлення в договірному порядку спеціальної правосуб'єктності держав-учасниць Спільноти відносно одна одної чи про спеціальний режим найбільшого сприяння, який виражається у застереженнях на кшталт «... без порушення компетенції та угод Спільноти...», «... не порушуючи інтересів Спільноти...», «із врахуванням інтересів Спільноти та державучасниць...» тощо.

Крім того, держави-учасниці делегують керівним органам Спільноти повноваження укладати угоди із державами-не-учасницями у сфері торгівлі послугами та торгівельних аспектів інтелектуальної власності. Але Органи договірного об'єднання не можуть укладати угоди, якщо вони містять положення, що виходять за межі внутрішніх повноважень Спільноти, зокрема коли укладення таких угод можуть призвести до необхідності гармонізації законів чи підзаконних актів держав-членів у сферах, де така гармонізація не передбачена. (ч. 6 ст. 133 Договору про $€ C)$. Це означає, що у держав-учасниць щодо укладення угод із іншими державами, третіми країнами та міжнародними організаціями зберігається повний економічний 
суверенітет (ч. 5 ст. 111; абз. 4 ч. 5 ст. 133 Договору про ЄС).

В результаті аналізу тексту різних редакцій договорів про $Є C$ можна виділити наявність організаційних та правових заходів регуляції відносин в середині співтовариства. При чому, основним завданням організаційних заходів регулювання відносин $\epsilon$ координування зближення держав та сприяння їх економічному співробітництву. Координація зближення держав відбувається в процесі проведення консультаційних заходів та заходів контролю, нагляду та моніторингу. Консультаційні заходи можуть мати позитивний результат, коли сторони дійшли згоди із конкретних питань, коли державиучасниці втілюють обумовлений в ході консультації результат у національне законодавство та економіку. I навпаки, консультації можуть не дати позитивного результату. В даному випадку Рада ЄC на пропозицію відповідного комітету, із яким проводились консультації, видає відповідні директиви або вживає інших доцільних заходів обумовлених в Договорі про ЄС (ст. 96).

Можливість держав-учасниць погоджуватись чи не погоджуватись із результатами консультацій підтверджує те, що держави-учасниці не передають власні суверенні права остаточно, але зберігають їх для можливості приймати рішення на власну користь. Звідси випливає, що Європейський Союз не набуває статусу суверена, який передбачає поєднання здатності від свого імені, самостійно і своїми силами здійснювати владні функції (Cymburskij, V. L. 1993). Крім того, відповідно до ч. 2 ст. 136 Договору про ЄС «...Спільнота та держави-члени виконують заходи 3 урахуванням відмінності національних звичаїв, зокрема у сфері договірних відносин, та потреби підтримувати конкурентоспроможність

економіки Спільноти...» (ч. 2 ст. 136).

Заходи контролю, та моніторингу націлені на забезпечення тісної координації економічних політик держав-членів з метою їх погодження із загальними настановами договірного співтовариства (ст. 99 ДЄС). Для відслідковування результативності зусиль держав-учасниць в договорі передбачається можливість застосування процедур різнобічного нагляду, які дають можливість відслідковувати рух держав-членів до економічного та валютного союзів, а також відслідковувати здійснення заходів направлених на гармонізацію національних законодавств. В результаті моніторингу, контролю та нагляду за діями держав-учасниць Співтовариство оцінює рівень виконання умов, що виставляються до виконання для знаходження в економічному союзі і залежно від рішення державу - держава-учасниця може бути обмежена в правосуб'єктності звільнена від певних прав та обов'язків (абз. 2 ч. 3 ст. 122 ДЄС) чи позбавлена права голосу (ч. 5 ст. 122 ДЄС). Дані заходи $\epsilon$ показником підпорядкованості держав-учасниць загальним правилам в договірному об'єднанні.

В результаті аналізу тексту Договору про ЄС можна констатувати використання таких правових способів регулювання як обмеження $\mathrm{ma}$ заборони. Практика законодавчих обмежень в міждержавних союзах застосовується в тих межах і до тих питань, які дозволяють їх конституційні засади держав-учасниць. (SHevchuk S. V. (2000). В Договорі про ЄС правові обмеження встановлені у вигляді негативних та позитивних приписів 3 приводу належної чи неналежної поведінки держав-учасниць, що виражаються здебільшого у словосполученнях «...не належить виходити за межі...», «...належить 
утримуватися від будь-яких кроків...», «...належить пристосувати...». Залежно від стану координації умов економічного співробітництва в договорі передбачається поступове скасовування встановлених обмежень (ч. 3 ст. 47 Договору про ЄС).

На ряду із доволі м'якими приписами, із якими погоджуються держави-учасниці, Договір про $Є \mathrm{C}$ встановлює велику кількість прямих імперативних заборон, які закріплюються як в окремих розділах документів, так і в статтях по всьому документу. Заборони стосуються кількісних обмежень експорту, імпорту, здійснення платежів, створення представництв, філій чи дочірніх підприємств, будь-яких зловживань домінуючим становищем та інших питань. Закріплюється право самих держав-учасниць встановлювати умови, випадки та міри заборони в економічній сфері. Але в особливо важливих випадках, наприклад щодо розробки та застосування конкретних випадків заборони щодо «...надання кредиту на покриття дефіциту чи будь-які інші кредити ЄЦБ чи центральних банків держав-членів...» керівні органи Спільноти (Рада ЄC) можуть встановлювати такі конкретні випадки заборони виходячи із власного розсуду (ч. 2 ст. 103 Договору про ЄC).

Договір визначає охоронні правові заходи направлені захист прав та інтересів міждержавного об'єднання. Зокрема, встановлюється застереження щодо застосування державамиучасницями заходів та процедур, які б порушували права кожної державичлена чи були б засобом свавільної дискримінації, що направлений проти спільної співпраці. (ч. 1, 3 ст. 58 Договору про ЄC). Окремо передбачені охоронні заходи направлені на захист прав та інтересів держав-учасниць, вжиття всіх потрібних заходів, наприклад, щодо запобіганню порушенню національних законів та підзаконних актів. Умови та строки застосування, потрібність та виправданість організаційних заходів, заходів охорони та захисту встановлюється Радою ЄС на власний розсуд. Але держава-член через серйозні політичні причини та через терміновість, може вжити однобічних заходів захисту, а Комісію та інших держав-членів може поінформувати про такі заходи постфактум.

За одночасної передачі повноважень Спільноті, щодо встановлення настанов, приписів, обмежень, заборон державамучасницям 3 приводу поведінки в договірному об'єднанні, а також вжиття в більшості випадків зазначених вище організаційних та правових заходів координації співпраці на свій розсуд, «...Спільнота не несе відповідальності й не перебирає зобов'язань центральних урядів, регіональних, місцевих чи інших державних органів...».

Таким чином, із наведених вище прикладів положень Договору про ЄС, держави-учасниці 3 одного боку держави добровільно погоджуються дотримуватись обмежень, заборон встановлених договірними документами $€ \mathrm{C}$, а з іншого проявляючи свій державний суверенітет в певних випадках і за певних умов застосовувати односторонні заходи захисту своїх прав та інтересів.

\section{ВИСНОВКИ}

За результатами проведеного дослідження, ми можемо стверджувати, що:

Договір про ЄС слугує основою для делегування державами-учасницями частини своїх повноважень наддержавним інституціям. Такий спосіб перерозподілу повноважень цілком відповідає конституційним принципам сталого співробітництва, субсидіарності і пропорційності, які $\epsilon$ характерними для відносин у міждержавних союзах. 
Всі застосовані в договірних актах про ЄС способи регулювання відносин можна поділити залежно від характеру заходів впливу на держав-учасниць на організаційні та правові. Організаційні заходи включають в себе заходи консультативного характеру та заходи моніторингу, контролю та нагляду. Консультативні заходи державучасниць із відповідними Комітетами Європейського Союзу спрямовані на координацію їх економічних політик із інтересами Європейського Союзу. За допомогою заходів моніторингу, контролю та нагляду відслідковується і оцінюється рівень ефективності тих заходів, які були здійснені державамиучасницями в ході економічного співробітництва. За результатами оцінки діяльності держав-учасниць обсяг їх правосуб'єктності в договірному об'єднанні може змінюватись.

Основними способами закріплення делегованих повноважень $\epsilon$ такі правові способи регулювання як заборони та

\section{References}

Falalieieva L. H. (2017). The role of the Copenhagen criteria in implementation of the European Union values. The Scienti ic Papers of the Legislation Institute of the Verkhovna Rada of Ukraine. 1. P. 114-122.

Dohovir (2005). Dohovir pro zasnuvannia Yevropeiskoi Spilnoty. Konsolidovana versiia stanom na 1 sichnia 2005

roku. https://zakon.rada.gov.ua/laws/sho w/994 017\#Text

Dohovir (2010). Nitstskyi dohovir pro vnesennia zmin ta dopovnen do Dohovoru pro Yevropeiskyi Soiuz, Dohovoriv pro zasnuvannia Yevropeiskykh Spivtovarystv ta deiakykh poviazanykh $\mathrm{z}$ nymy aktiv (2001/C80/01). Konsolidovana versiia Dohovoru pro Yevropeiskyi Soiuz ta Dohovoru pro funktsionuvannia Yevropeiskoho Soiuzu $\mathrm{z}$ protokolamy ta обмеження. Обмеження $\epsilon$ правовими способами регулювання відносин i направлені на встановлення меж, які вказують на обсяги необхідної конкретизації змісту рішень держав, які можна i необхідно приймати в ході економічного співробітництва. Заборони $\epsilon$ правовими способами регулювання відносин в міждержавному союзі і направлені на охорону та захист економічних інтересів співтовариства і сталого функціонування його інституцій.

Фактично існує протистояння національних інтересів державучасниць $\epsilon$. Договір про $\epsilon C$ юридичними засобами закріплює концепцію економічного співробітництва європейських країн, а це означає, що в договорі встановлено порядок (регламент) не скільки урівноважування інтересів держав, скільки розподілу і перерозподілу ризиків, що з'являються в наслідок входження країни в договірне об’єднання.

deklaratsiiamy stanom na 30 bereznia 2010

roku. https://zakon.rada.gov.ua/laws/sho w/994 261\#Text

Butorina, 0. (2001). Ekonomicheskij i valyutnyj soyuz ES (mezhdunarodnyj aspekt). [Doktorskaya disertaciya, MGIMO] Elektronnaya biblioteka dissertacij. Otkryt': http://www.dslib.net/economikamira/jekonomicheskij-i-valjutnyj-sojuzes.html

Butorina, 0. (2005) Ponyatie regional'noj integracii : novye podhody. Kosmopolis. 3 (13). S. 136-145.

Petryshyn, O. V. (2010) Problemy realizatsii derzhavnoho suverenitetu $\mathrm{V}$ ekonomichnii ta finansovii sferakh $\mathrm{v}$ umovakh hlobalizatsii. V Yu. P. Bytiak \& I. V. Yakoviuk (red.). Derzhavnyi suverenitet: teoretyko-pravovi problemy. (Stor. 243268.) Kharkiv: Pravo. 
Salo, V. I. (2007). Vnutrishni funktsii derzhavy $\mathrm{v}$ umovakh chlenstva $\mathrm{v}$ Yevropeiskomu Soiuzi [Kandydatska dysertatsiia, Naukovo-doslidnyi instytut derzhavnoho budivnytstva ta mistsevoho samovriaduvannia Akademii pravovykh nauk

Ukrainy] https://dspace.nlu.edu.ua/bitstream/ 123456789/7859/1/Salo_2007_dis.pdf

Siur, N. V. (2006). Pravova intehratsiia Ukrainy do Yevropeiskoho Soiuzu: teoretyko-pravove doslidzhennia [Kandydatska dysertatsiia, Kyivskyi natsionalnyi unversytet vnutrishnikh sprav] Elektronna biblioteka dysertatsii. http://www.disslib.org/pravovaintehratsia-ukrayiny-do-yevropejskohosojuzu-teoretyko-pravove-doslidzhennja.html

Yakoviuk, I.V. (2004). Derzhavnyi suverenitet natsionalnykh derzhav u skladi Yevropeiskoho Soiuzu: problemy vyznachennia. Visnyk Akademii pravovykh nauk Ukrainy. 3. S. 114-126

Yakoviuk, I.V. (2010). Osoblyvosti vplyvu nadnatsionalnoi orhanizatsii na derzhavnyi suverenitet krain-kandydativ ta krain-susidiv (na prykladi Yevropeiskoho Soiuzu). Visnyk Akademii pravovykh nauk Ukrainy. 3. C. 19-31.

Yakoviuk, I.V. (2013). Pravovi osnovy intehratsii do YeS: zahalnoteoretychnyi analiz. Kharkiv: Pravo. 760 s.

Bruno de Witte (1995) Sovereignty and European Integration: The Weight of Legal Tradition. Maastricht Journal of European and Comparative Law. Vol. 2 iss.
2.

P. $145-$

173. https://doi.org/10.1177/1023263X9 $\underline{500200204}$

David A., Lake. (2006).Delegating Divisible Sovereignty: Some Conceptual Issues. Prepared for the Workshop on "Delegating Sovereignty: Constitutional and Political Perspectives". Duke University Law School. March 34. https://web.law.duke.edu/publiclaw/pdf/wo rkshop06sp/lake.pdf

Bieber, R. (2009) An Association of Sovereign States. European Constitutional Law Review. Vol. 5.Iss. 3. pp. 391 - 406. DOI: https://doi.org/10.1017/S157401960 $\underline{9003915}$

Oona A., Hathaway. (2008) International Delegation and State Sovereignty. Law and Contemporary Problems. Vol. 71. (1). pp. 115-149.

Klemin, A. V. (1996) Evropejskij soyuz i gosudarstva-uchastniki: vzaimodejstvie pravovyh poryadkov (praktika FRG). Kazan'.

Cymburskij, V. L. (1993). Ideya suvereniteta $\mathrm{v}$ posttotalitarnom kontekste. Polis. 1. S. 19-20.

SHevchuk S. V. (2000) Znachennya zagal'nopravovogo principu proporcijnosti dlya viznachennya konstitucijnosti zakonodavchih obmezhen' shchodo realizaciï konstitucijnih prav i svobod (zarubizhnij dosvid). Visnik Akademiï pravovih nauk Ukraïni. 1. S. 69-76. 